\title{
Efficiency, economics, and environmental implications of phosphorus resource use and the fertilizer industry in China
}

\author{
Weifeng Zhang $\cdot$ Wenqi Ma $\cdot$ Yuexiu Ji $\cdot$ \\ Mingsheng Fan $\cdot$ Oene Oenema $\cdot$ Fusuo Zhang
}

Received: 6 November 2006/ Accepted: 23 July 2007/Published online: 2 September 2007

(C) Springer Science+Business Media B.V. 2007

\begin{abstract}
Phosphorus (P) is an essential nutrient for crop production and is often in short supply. The necessary $\mathrm{P}$ fertilizers are derived from deposits in the lithosphere, which are limited in size and nonrenewable. China is one of the world's largest consumers and producers of $\mathrm{P}$ fertilizers. Thus, $\mathrm{P}$ resource use efficiency in China has an important impact on the worldwide efficiency of $\mathrm{P}$ resource use. This study examined the $\mathrm{P}$ fertilizer industry in China in terms of $\mathrm{P}$ resource use efficiency, economics, and environmental risk, and explored options for improvement through scenario analysis. $\mathrm{P}$ resource use efficiency decreased from a mean of $71 \%$ before
\end{abstract}

W. Zhang $\cdot$ M. Fan $\cdot$ F. Zhang ( $₫)$

College of Resources and Environmental Sciences, China Agricultural University, Beijing 100094, P.R. China e-mail: zhangfs@cau.edu.cn

W. Ma

College of Resources and Environmental Sciences, Agricultural University of Hebei, Baoding 071001, P.R. China

Y. Ji

Institute of Information on Agricultural Science and Technology, Beijing Academy of Agriculture and Forestry Sciences, Beijing 100097, P.R. China

O. Oenema $(\bowtie)$

Wageningen UR, Alterra, P.O. Box 47,

Wageningen 6700 AA, The Netherlands

e-mail: Oene.Oenema@wur.nl
1995 to $39 \%$ in 2003 , i.e., from every $10 \mathrm{~kg} \mathrm{P}$ in rock material, only $3.9 \mathrm{~kg} \mathrm{P}$ was used to produce fertilizer, $5.6 \mathrm{~kg}$ of the residues were discarded at the mining site, and $0.5 \mathrm{~kg}$ was manufacturing waste. The decreased efficiency was caused by increased $\mathrm{P}$ rock mining activities, especially from small, inefficient miners. Enhanced mining was supported by local governments and by the growing $\mathrm{P}$ fertilizer industry, where high-analysis $\mathrm{P}$ fertilizers have fourfold higher gross margins than traditional low-analysis fertilizers. Although the growing fertilizer industry is contributing significantly to the development of some regions, the economic efficiency is still lower than in other countries, e.g., in the USA. The $\mathrm{P}$ resource is depleting quickly, and the environmental consequences of inefficient use are serious. The amount of accumulated phosphor gypsum was estimated to be $110 \mathrm{Tg}$, the amount of deteriorated land reached $475 \mathrm{~km}^{2}$, and the consumption of ground water was 1.8 billion $\mathrm{m}^{3}$ per year. The low efficiency and serious environmental risk could be attributed to the numerous small inefficient miners, which were supported by intervention of governmental subsidies and taxes after 1995. This study proved that there is a great deal of room for improvement in the resource use efficiency up to $77 \%$ by integrated measures, which need broad cooperation of miners, fertilizer plants, and agriculture.

Keywords Phosphorus - Efficiency ·

Fertilizer industry · China 


\section{Introduction}

Chemical phosphorus $(\mathrm{P})$ fertilizers were introduced in the second half of the nineteenth century, and consumption took off in the second half of the twentieth century. Global $\mathrm{P}$ fertilizer use has increased from about $2 \mathrm{Tg}\left(1 \mathrm{Tg}=10^{12} \mathrm{~g}=1 \mathrm{mil}-\right.$ lion tons) in 1890 to $4 \mathrm{Tg}$ in 1950 and $15 \mathrm{Tg}$ in 2000 (Murray 2003). That has greatly contributed to the increase of food and feed production but, on the other hand, has contributed to the eutrophication of the surface waters and the loss of biodiversity (Arrigo 2005; Beman et al. 2005). The demand for the chemical fertilizers will keep increasing in the next decades, as the global populations of humans and animals will increase by some $30-60 \%$ (Alexandratos and Haen 1995), especially in Asia, Latin America, Oceania, and Africa (IFA 2004).

The production and consumption of $\mathrm{P}$ fertilizers in China increased greatly during the last two decades driven by the huge financial support from government by more than 40 billion RMB annually to the fertilizer industry (Zhang et al. 2007). China became the largest consumer (30\% of the total of the world in 2002) and the second largest producer of $P$ fertilizers (23\%, IFA 2004). The forecasts suggest that the demand for fertilizer will increase further as the population grows from 1.3 billion in 2000 to 1.6 billion in 2030. Increase in meat consumption is also expected, and the country will require a $60 \%$ increase in grain production, from $460 \mathrm{Tg}$ in 2000 to $750 \mathrm{Tg}$ in 2030 (Cai 2004).

Unlike nitrogen $(\mathrm{N})$, the resources for $\mathrm{P}$ fertilizer production are limited. The known $\mathrm{P}$ rock deposits in the world are sufficient for 100-1,000 years, depending on the efficiency of resource use during $\mathrm{P}$ fertilizer production and on the use of these fertilizers in the next decades (Tinker 1977; Smil 2000). China is the second largest holder of $\mathrm{P}$ rock deposits in the world. Its available deposit has been estimated at $1.2 \mathrm{Pg}\left(1 \mathrm{Pg}=10^{15} \mathrm{~g}\right) \mathrm{P}_{2} \mathrm{O}_{5}$ (equivalent to $500 \mathrm{Tg} \mathrm{P}$ ) in 2002 (USGS 2004). About $80 \%$ of the deposits are of sedimentary origin and have low quality; $70 \%$ has been classified as low grade, with less than $23 \% \mathrm{P}_{2} \mathrm{O}_{5}$ $(10 \% \mathrm{P})$, and only $7 \%\left(0.37 \mathrm{Pg}_{2} \mathrm{O}_{5}\right)$ as high-grade $\mathrm{P}$ rock resources, with more than $30 \% \quad \mathrm{P}_{2} \mathrm{O}_{5}$ (Zhang et al. 2005b). However, it has been forecasted that China will exhaust its high-grade $\mathrm{P}$ rock resources by 2014 and the total available deposit by 2050 if fertilizer use continues to increase at the current rate (Zhang et al. 2005b). Therefore, improvement in the management of $\mathrm{P}$ resources is urgently required.

Meanwhile, these massive increases in $\mathrm{P}$ use will likely be followed by further environmental damage if no controlling measures are taken (Liu and Diamond 2005; Zhang et al. 2005a). The environmental consequences of $\mathrm{P}$ rock mining and the fertilizer industry include: (1) the use and degradation of land and landscape damage at mining sites, landfills, and dumping sites; (2) massive use of water for the transport and beneficiation (separating $\mathrm{P}$ rock from clay) of P rock; and (3) water and air (dust) pollution by the phosphor gypsum and other wastes (Brown 2005; Lv et al. 2002). But environmental damage has rarely been discussed in China.

Considerable research has been done to improve $\mathrm{P}$ fertilizer use efficiency in the agricultural sector. Liu et al. (2004) recently explored P flows in China and proposed possible measures to limit or prevent environmental deterioration by controlling $\mathrm{P}$ use in farmland, in animal production, and in human daily life at reasonable levels. However, information is still lacking on $\mathrm{P}$ flow partitioning and $\mathrm{P}$ use efficiency in $\mathrm{P}$ rock mining and $\mathrm{P}$ fertilizer manufacturing, and only few measures have been indicated to save resources in these processes. Given the steadily increasing demand for $\mathrm{P}$ fertilizers and the limited available rock $\mathrm{P}$ resources, $\mathrm{P}$ resource use efficiency must be improved and mechanisms should be well understood. P losses must be reduced in both the agricultural production sector and the industrial manufacturing process.

Therefore, the objectives of this study were to: (1) present $\mathrm{P}$ resource use in the Chinese $\mathrm{P}$ fertilizer industry and analyze its efficiency, (2) identify and explore the possible reasons for the decrease in efficiency of the $\mathrm{P}$ fertilizer industry in China by economic evaluation, (3) assess the environmental implications of the $\mathrm{P}$ fertilizer industry, and (4) discuss potential targets for improvement through scenario evaluation.

\section{Materials and methods}

Substance flow analysis

A substance flow analysis (SFA) model was designed to better describe the entire process of $\mathrm{P}$ flux in the 
fertilizer industry and to analyze the resource use efficiency. Model boundaries were set to cover the $\mathrm{P}$ fertilizer industry from mining to the production of $\mathrm{P}$ products. The model generated information on fertilizer production, which was used to calculate resource use efficiency (RUE), the final output of the model. RUE is defined here as the percentage of $P$ in matrix rock that ends up in $\mathrm{P}$ fertilizer. The higher the RUE, the better the industry in terms of $\mathrm{P}$ resource use efficiency. To analyze the RUE in the two important processes of the fertilizer industry, RUE (\%) was further subdivided into (a) RUE in mining or P rock recovery rate $\left(\mathrm{RUE}_{1}, \%\right)$ measuring the percentage of $\mathrm{P}_{2} \mathrm{O}_{5}$ in matrix rock that ends up in the refined rock, and (b) RUE during fertilizer manufacturing $\left(\mathrm{RUE}_{2}\right.$, $\%$ ) measuring the percentage of $\mathrm{P}_{2} \mathrm{O}_{5}$ in refined rock that ends up in the fertilizer products. The detailed method to calculate the RUE is described here:

$$
\begin{aligned}
& \text { RUE }=\mathrm{RUE}_{1} \times \mathrm{RUE}_{2} \div 100 \\
& \mathrm{RUE}_{1}=\left(P_{\mathrm{rr}} \div P_{\mathrm{mr}}\right) \times 100 \\
& \mathrm{RUE}_{2}=\left(P_{\mathrm{pf}} \div P_{\mathrm{rrf}}\right) \times 100 \\
& P_{\mathrm{rr}}=P_{\mathrm{rrf}}+P_{\mathrm{p}^{4}}+P_{\mathrm{af}}+P_{\mathrm{e}} \\
& P_{\mathrm{mr}}=P_{\mathrm{rrb}} \div \mathrm{RUE}_{1-1}+P_{\mathrm{rrs}} \div \mathrm{RUE}_{1-2} \\
& P_{\mathrm{pf}}=\sum_{i=1}^{7} P i \\
& P_{\mathrm{rrf}}=\sum_{i=1}^{7} P i \div R i
\end{aligned}
$$

$P_{\mathrm{rr}}(\mathrm{Tg})$ and $P_{\mathrm{mr}}(\mathrm{Tg})$ refer to the amount of $\mathrm{P}_{2} \mathrm{O}_{5}$ in the refined rock and in the matrix rock respectively; $P_{\text {rrf }}(\mathrm{Tg}), P_{\mathrm{P}^{4}}(\mathrm{Tg}), P_{\mathrm{af}}(\mathrm{Tg})$ and $P_{\mathrm{e}}(\mathrm{Tg})$ refer to the amount of $\mathrm{P}_{2} \mathrm{O}_{5}$ in refined rock used for fertilizer, $\mathrm{P}_{2} \mathrm{O}_{5}$ in $\mathrm{P}_{4}, \mathrm{P}_{2} \mathrm{O}_{5}$ in animal feed, and $\mathrm{P}_{2} \mathrm{O}_{5}$ for export, respectively; $P_{\text {rrb }}(\mathrm{Tg})$ and $P_{\text {rrs }}(\mathrm{Tg})$ refer to the amount of $\mathrm{P}_{2} \mathrm{O}_{5}$ in refined rock from big mines and small mines, respectively; $\operatorname{RUE}_{1-1}(\%)$ and $\mathrm{RUE}_{1-2}(\%)$ refer to the $\mathrm{P}$ rock recovery rate in big mines and small mines, respectively, which were derived from the reference directly. $P_{\mathrm{pf}}(\mathrm{Tg})$ refers to the amount of $\mathrm{P}_{2} \mathrm{O}_{5}$ in all $\mathrm{P}$ fertilizer; $P_{i}(\mathrm{Tg})$ and $R_{i}$ $\left(\mathrm{t} / \mathrm{t}\right.$ of $\left.\mathrm{P}_{2} \mathrm{O}_{5}\right)$ refer to the amount of $\mathrm{P}_{2} \mathrm{O}_{5}$ in each $\mathrm{P}$ fertilizer product and refined phosphate rock consumption per unit of fertilizer products, respectively; $i=1-7$ refers to the $\mathrm{P}$ fertilizer products of diammonium phosphate (DAP), monoammonium phosphate (MAP), compound fertilizer (NPK), triple straight phosphate (TSP), nitrate phosphate (NP), single superphosphate (SSP), and fused calcium magnesium phosphate (FMP).

Data for $R_{i}$ and $\mathrm{P}_{2} \mathrm{O}_{5}$ content of $\mathrm{P}$ fertilizer products $\left(C_{i}\right)$ (Table 1) came from an industry survey, which was conducted in cooperation with the China Phosphate Fertilizer Industry Association (CPFIA) in (2004). Data and information were collected in interviews in more than 48 main $\mathrm{P}$ fertilizer plants in China by using a questionnaire implemented by CPFIA. These plants are relatively large, and their production of $\mathrm{P}_{2} \mathrm{O}_{5}$ accounted for $78 \%$ for DAP, $46 \%$ for MAP, $51 \%$ for NPK, $95 \%$ for TSP, and $100 \%$ for NP in China in 2003. Two of them have their own $\mathrm{P}$ rock mine. Published data (Fan 2001) were also used to calibrate some indices because the survey data did not include SSP, FMP, or all types of NPK plants. Similar data from the USA (Table 1) came from the Web site of IMC (2004) and Decyfer Ltd (2005).

The time series between 1961 and 2003 on the production and export of total $\mathrm{P}$ fertilizer $\left(P_{\mathrm{pf}}\right.$ and $\left.P_{\mathrm{e}}\right)$ came from the Food and Agriculture Organization of United Nation statistical database (UN-FAO 2004). The data of production of refined $\mathrm{P}$ rock $\left(P_{\mathrm{rr}}\right)$ before 1996 came from the UN-FAO database (2004) and Chinese data (China Statistics Bureau 2004) for the period after 1996. The production in refined P rock of big miners $\left(P_{\text {rrb }}\right)$ came from the China Statistics Bureau (2004) and that of small miners $\left(P_{\text {rrs }}\right)$ after 1996 came from the published data of Lin (2003). Data on the production of different $\mathrm{P}$ products $\left(P_{i}\right.$, $P_{\mathrm{P}^{4}}$ and $\left.P_{\mathrm{af}}\right)$ came, again, from the China Statistics Bureau (2004). The recovery rate of different kinds of mines in China ( $\mathrm{RUE}_{1-1}$ and $\mathrm{RUE}_{1-2}$ ) came from the statistical data of CPFIA (2004). CPFIA is an official body responsible for the management, data collection, and information service for the government and fertilizer industry in China. Their statistical data is published in yearbooks from 1994, which contain data on most of the fertilizer producing plants in China.

Economic efficiency and environment evaluation

The economic evaluation of the $\mathrm{P}$ fertilizer industry aims to find differences in profitability of the 
Table 1 Phosphorus $(\mathrm{P})$ consumption rate by fertilizer product and the products' quality in China and the USA $\left(\mathrm{P}_{2} \mathrm{O}_{5}\right)$

\begin{tabular}{|c|c|c|c|c|c|c|c|}
\hline \multirow[t]{2}{*}{ Countries } & \multirow[t]{2}{*}{ Item } & \multicolumn{6}{|c|}{ Fertilizer products } \\
\hline & & TSP & MAP & DAP & NP & NPK & SSP/FMP \\
\hline \multirow[t]{2}{*}{ China $^{\mathrm{a}}$} & $C_{i}(\%)$ & 46 & 44 & 46 & 12 & 15 & 14 \\
\hline & $R_{i}\left(\mathrm{t} / \mathrm{t}\right.$ of $\left.\mathrm{P}_{2} \mathrm{O}_{5}\right)$ & 1.041 & 1.188 & 1.124 & 1.125 & 1.126 & 1.157 \\
\hline \multirow[t]{2}{*}{$\mathrm{USA}^{\mathrm{b}}$} & $C_{i}(\%)$ & 46 & 51 & 46 & 12 & 15 & $18-20$ \\
\hline & $R_{i}\left(\mathrm{t} / \mathrm{t}\right.$ of $\left.\mathrm{P}_{2} \mathrm{O}_{5}\right)$ & 1.041 & 1.100 & 1.089 & 1.125 & 1.126 & 1.024 \\
\hline
\end{tabular}

TSP triple straight super phosphate, DAP diammonium phosphate, MAP monoammonium phosphate, SSP single super phosphate, $N P$ nitrate phosphate, $N P K$ compound fertilizer, $F M P$ fused calcium magnesium phosphate

${ }^{a}$ In NPK processing, raw materials conform to $50 \% \mathrm{P}_{2} \mathrm{O}_{5}$ phosphoric acid + MAP + ammonia + ammonium nitrate + KCl; Data of SSP/FMP came from Fan (2001) and the rest came from industry survey (2004)

b Data came from the Web site of IMC (2004) and Decyfer Ltd (2005)

$C_{i}$ and $R_{i}$ refer to the product's quality indicated by the $\mathrm{P}_{2} \mathrm{O}_{5}$ content in the products (\%) and the refined phosphate rock consumption per unit of product $\left(\mathrm{t} / \mathrm{t}\right.$ of $\left.\mathrm{P}_{2} \mathrm{O}_{5}\right)$

different products and different phases of the entire production chain and to explain the reasons for the changes in the $\mathrm{P}$ fertilizer industry. Based on the industry survey data, the economics of the fertilizer industry were evaluated in terms of cost (yuan/ton), factory price (yuan/ton), trade price (yuan/ton), retail price (yuan/ton), and gross profit (yuan/ton). Each index was calculated as the average for all the interviewed plants. The prices in each part of the chain consisted of the cost and the profit of the operators. The gross profit was calculated from the retailer price and cost. Average cost/price per ton $\mathrm{P}_{5} \mathrm{O}_{2}$ is the average of all products weighted by their percentage in the total $\mathrm{P}_{2} \mathrm{O}_{5}$ production and their $\mathrm{P}_{2} \mathrm{O}_{5}$ content in 2003 .

The economic efficiency of miners and fertilizer producers in China was compared with that of the USA with the help of several indices, including the number of employees per plant (capita), production per employee (ton $\mathrm{P}_{2} \mathrm{O}_{5}$ /capita), net sale per employee (US \$/capita), and gross margin per employee (US \$/capita). These indices were calculated from total production, total net sales, and gross margin of the entire industry divided by the number of total employees of the industry. Economic data on the entire $\mathrm{P}$ rock mine and $\mathrm{P}$ fertilizer industry in China came from CPFIA statistics, and US data came from the U.S. Geological Survey (USGS 2004) and IMC, a fertilizer company in the USA now called MOSAIC (IMC 2004).

Three types of environmental indicators were used to evaluate the environmental consequences of the $\mathrm{P}$ fertilizer industry in China. US parameters were used as the reference for China because China' parameters were scarce. The first indicator is the total land area $\left(\mathrm{km}^{2}\right)$ occupied by $\mathrm{P}$ rock mining and fertilizer processing, which was estimated as about $2.7 \mathrm{~m}^{2}$ land per ton $\mathrm{P}_{2} \mathrm{O}_{5}$ of refined rock in the USA (FIPR 2005). The second is the amount of water $\left(\mathrm{m}^{3}\right)$ used for the transport and beneficiation of $\mathrm{P}$ rock. It was reported that $37.9 \mathrm{~m}^{3}$ water is used for the production of $1,000 \mathrm{~kg}$ refined ore (FIPR 2005). The third index is the production of phosphor gypsum and other wastes (Tg): $5 \mathrm{~kg}$ of phosphor gypsum are produced to manufacture $1 \mathrm{~kg}$ of phosphoric acid, which is needed for the production of high-analysis $\mathrm{P}$ fertilizers (Rutherford et al. 1994). The environmental risk related to the $\mathrm{P}$ fertilizer industry in China was evaluated and is discussed by using these indices multiplied with the production of $\mathrm{P}$ rock and $\mathrm{P}$ fertilizer.

\section{Scenario evaluation}

From the definition in "substance flow analysis," the RUE is determined by some basic indices, such as fertilizer production $\left(P_{i}\right)$, phosphate rock consumption per unit fertilizer products $\left(R_{i}\right)$, P rock recovery rate in different mines $\left(\mathrm{RUE}_{1-1}\right.$ and $\left.\mathrm{RUE}_{1-2}\right)$ and even $\mathrm{P}_{2} \mathrm{O}_{5}$ content in $\mathrm{P}$ fertilizer products $\left(C_{i}\right)$. Although each index is seemingly decided by technology, they could be changed by policies because the Chinese fertilizer industry is supported and protected by the 
government. Usual policies are financial support for investment, subsidy for production and transportation, and price fixing for raw material and products (Zhang et al. 2007). For instance, the Chinese government has invested more than US \$6 billion in a few big, state-owned enterprises and has imposed low tax on fertilizer production (no added-value tax for P fertilizer products except for DAP after 2000) in order to develop the $\mathrm{P}$ fertilizer industry, especially the high-analysis P fertilizers, including DAP, MAP, NPK, TSP, and NP since 1990. The government keeps the selling price of $\mathrm{P}$ rock used for $\mathrm{P}$ fertilizer production at a low level by low tax rates (Pan 2003). The government implements a low standard for $\mathrm{P}$ fertilizer products, for example, requiring the citratesoluble $\mathrm{P}_{2} \mathrm{O}_{5}$ content of SSP and MAP to be $12 \%$ and $44 \%$ respectively, which are lower than international standards. The government applies a low standard for producer entry into the $\mathrm{P}$ rock mining and $\mathrm{P}$ fertilizer production businesses and never prescribes their technology level.

It was assumed that RUE would change after canceling these policies or implementing some new policies. Fertilizer production is the key process influencing RUE, and two basic scenarios are distinguished: P fertilizer production grows in scenarios 1 and 2 but remains fixed at the 2003 level in scenarios 3 and 4, which can be achieved by investment policies. Two additional subscenarios are included within these two basic variants of scenarios on the basis of different targets (Table 2).

Scenario 1 involves, for example, that $\mathrm{P}$ rock with $26 \% \mathrm{P}_{2} \mathrm{O}_{5}$ should be used for MAP production and with $16 \% \mathrm{P}_{2} \mathrm{O}_{5}$ for SSP and FMP production instead of $\mathrm{P}$ rock with $30 \% \mathrm{P}_{2} \mathrm{O}_{5}$ used for all $\mathrm{P}$ fertilizers products. It was assumed that some low-grade rock could be used directly without beneficiation for MAP/ SSP/FMP. In this way, the recovery rate of these rocks could be improved to the average of all big mines. With the implementation of quality control for fertilizer products in scenario 2 , the quality of the $\mathrm{P}$ fertilizers should comply with international standards: plant-available $\mathrm{P}_{2} \mathrm{O}_{5}$ content of MAP should reach $51 \%$ instead of the current mean of $44 \%$ and $20 \%$ SSP/FMP instead of $14 \%$. And P rock use per unit product should reach the international standard, such as the USA level in Table 1.

In scenario 3, it was assumed that the recovery rate of $\mathrm{P}$ rock used for all $\mathrm{P}$ fertilizer products would be enhanced to the level of big mines in China. All improvements in the other three scenarios were included in scenario 4 . In this case, $\mathrm{P}$ rock recovery rate and $\mathrm{P}$ fertilizer production efficiency would be increased to the level of big miners in China and the level of the USA, respectively, through policy measures.

\section{Results}

Phosphorus flows and efficiency of the Chinese fertilizer industry in 2003

Figure 1 presents an overview of $\mathrm{P}$ flows in the fertilizer industry in China in 2003. A total of 31.67 Tg of $\mathrm{P}_{2} \mathrm{O}_{5}$ (equivalent to $13.83 \mathrm{Tg} \mathrm{P}$ ) was mined as rock phosphate. More than half of this rock phosphate $(15.90 \mathrm{Tg})$ was discarded and dumped in order to produce $6.81 \mathrm{Tg}$ of commercially applicable refined ore without beneficiation by small mines $\left(\mathrm{RUE}_{1-2}=30 \%\right)$. About $8.96 \mathrm{Tg}$ in raw ore was required to yield $7.34 \mathrm{Tg}$ refined $\mathrm{P}_{2} \mathrm{O}_{5}$ through beneficiation at large mines and produced $1.62 \mathrm{Tg}$ in waste (clay, which is dumped; $\operatorname{RUE}_{1-1}=81.9 \%$ ). Hence, the RUE in the mining process $\left(\mathrm{RUE}_{1}\right)$ was about $45 \%$. Roughly $19 \%$ of the refined ore was used

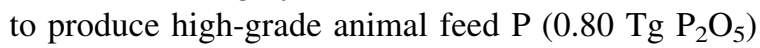
and yellow $\mathrm{P}\left(1.83 \mathrm{Tg}_{2} \mathrm{O}_{5}\right)$. The latter is formulated $\mathrm{P}_{4}$, which is a basic raw material for the chemical industry and pesticides, whereas $1.05 \mathrm{Tg} \mathrm{P}_{2} \mathrm{O}_{5}$ of refined rock was exported in 2003 . The other $74 \%$ of the refined ore was used to produce $\mathrm{P}$ fertilizer as follows:

About 5.32 $\mathrm{Tg} \mathrm{P}_{2} \mathrm{O}_{5}$ (equivalent to $2.32 \mathrm{Tg} \mathrm{P}$ ) in refined $\mathrm{P}$ rock phosphate was used to produce $4.58 \mathrm{Tg}$ plant-available $\mathrm{P}_{2} \mathrm{O}_{5}$ in low-analysis fertilizers by (a) dissolution with sulfuric acid to produce SSP and (b) electric heating to produce FMP. The average total $\mathrm{P}_{2} \mathrm{O}_{5}$ content of these two low-analysis $\mathrm{P}$ fertilizers was usually lower than $14 \%$, out of which just $86 \%$ could be readily absorbed by plants (averages of the available $\mathrm{P}$ content in the fertilizer products were calculated using the survey data). Therefore, the remaining $14 \% \quad\left(0.74 \mathrm{Tg} \quad \mathrm{P}_{2} \mathrm{O}_{5}\right)$ although contained in the $\mathrm{P}$ fertilizer products, was assumed to be lost during the manufacturing process.

Another 5.15 Tg $\mathrm{P}_{2} \mathrm{O}_{5}$ (equivalent to $2.25 \mathrm{Tg} \mathrm{P}$ ) was upgraded to yield phosphoric acid (4.54 Tg 
Table 2 Scenarios to increase phosphorus (P) resource use efficiency in China in 2010

\begin{tabular}{|c|c|c|c|c|}
\hline Scenarios & $\begin{array}{l}\text { National production of } \\
\mathrm{P} \text { fertilizer as forecast } \\
\text { for } 2010 \text { based on }^{\mathrm{a}} \\
\text { industry survey }^{\mathrm{a}}\end{array}$ & $\begin{array}{l}\text { Grade of } \mathrm{P} \text { rock used } \\
\text { for production } \\
\text { of } \mathrm{P} \text { fertilizers }{ }^{\mathrm{b}}\end{array}$ & $\begin{array}{l}\text { Quality of P fertilizer } \\
\text { products }^{c}\end{array}$ & Recovery rate of $\mathrm{P}$ rock $^{\mathrm{d}}$ \\
\hline Business as usual & $\begin{array}{l}\text { Usual level in } \\
\text { China in } 2003^{\mathrm{e}}\end{array}$ & $\begin{array}{l}\text { Usual level in } \\
\text { China in } 2003^{\mathrm{e}}\end{array}$ & Usual level in China in $2003^{\mathrm{e}}$ & Usual level in China in $2003^{\mathrm{e}}$ \\
\hline Scenario 1 & $\begin{array}{l}\text { Increase as forecast } \\
\quad \text { for } 2010^{\mathrm{f}}\end{array}$ & $\begin{array}{l}\text { Different rock for } \\
\text { different } \mathrm{P} \text { fertilizer }\end{array}$ & Usual level in China in $2003^{\mathrm{e}}$ & Usual level in China in $2003^{\mathrm{e}}$ \\
\hline Scenario 2 & $\begin{array}{l}\text { Increase as forecast } \\
\text { for } 2010^{\mathrm{f}}\end{array}$ & $\begin{array}{l}\text { Usual level in } \\
\text { China in } 2003^{\mathrm{e}}\end{array}$ & Develop to international level ${ }^{\mathrm{f}}$ & Usual level in China in $2003^{\mathrm{e}}$ \\
\hline Scenario 3 & $\begin{array}{l}\text { Usual level in China } \\
\text { in } 2003^{\mathrm{e}}\end{array}$ & $\begin{array}{l}\text { Usual level in } \\
\text { China in } 2003^{\mathrm{e}}\end{array}$ & Usual level in China in $2003^{\mathrm{e}}$ & $\begin{array}{l}\text { The level attained by big } \\
\text { mines in China }{ }^{f}\end{array}$ \\
\hline Scenario 4 & $\begin{array}{l}\text { Usual level in China } \\
\text { in } 2003^{\mathrm{e}}\end{array}$ & $\begin{array}{l}\text { Different rock for } \\
\text { different } \mathrm{P} \text { fertilizer }^{\mathrm{f}}\end{array}$ & Develop to international level ${ }^{\mathrm{f}}$ & $\begin{array}{l}\text { The level attained by big } \\
\text { mines in China }{ }^{\mathrm{f}}\end{array}$ \\
\hline
\end{tabular}

SSP single super phosphate, FMP fused calcium magnesium phosphate, MAP monoammonium phosphate, DAP diammonium phosphate, TSP triple straight super phosphate, NP nitrate phosphate, NPK compound fertilizer

${ }^{a}$ Based on the industry survey, the total forecasted $\mathrm{P}$ fertilizer production would be $12.8 \mathrm{Tg} \mathrm{P}_{2} \mathrm{O}_{5}$ in 2010, including: 3.9 Tg $\mathrm{P}_{2} \mathrm{O}_{5}$ in SSP, 0.7 Tg $\mathrm{P}_{2} \mathrm{O}_{5}$ in FMP, 3.9 Tg $\mathrm{P}_{2} \mathrm{O}_{5}$ in MAP, $2.3 \mathrm{Tg} \mathrm{P}_{2} \mathrm{O}_{5}$ in DAP, $0.38 \mathrm{Tg} \mathrm{P}_{2} \mathrm{O}_{5}$ in TSP, $0.1 \mathrm{Tg} \mathrm{P}_{2} \mathrm{O}_{5}$ in NP, and $1.5 \mathrm{Tg} \mathrm{P}_{2} \mathrm{O}_{5}$ in NPK

b As usual business practice, $\mathrm{P}$ rock with the grade of $30 \% \mathrm{P}_{2} \mathrm{O}_{5}$ is used for all $\mathrm{P}$ fertilizers but restricting the use of $\mathrm{P}$ rock with $26 \%$ $\mathrm{P}_{2} \mathrm{O}_{5}$ for MAP and with $16 \% \mathrm{P}_{2} \mathrm{O}_{5}$ for SSP and FMP in the advanced level which assume this part of $\mathrm{P}$ rock would be mined in a advanced recovery rate as big mines

c The quality levels of $\mathrm{P}$ fertilizers are enhanced to reach those of American plants (see Table 1)

$\mathrm{d}$ The recovery rate of $\mathrm{P}$ rock is increased from $45 \%$ (usual level) to $81.9 \%$ (the level attained by big mines in China)

e The usual level in China in 2003

${ }^{\mathrm{f}}$ Develop to advanced level

Fig. 1 Phosphorus (P) flows in the Chinese fertilizer industry in 2003. Arrows indicate the relative size and direction of the $\mathrm{P}$ flows; Number near arrows indicates the estimated amount, in $\mathrm{Tg}(\mathrm{Mt}) \mathrm{P}_{2} \mathrm{O}_{5}$ $\left(1 \mathrm{~kg} \mathrm{P}=2.29 \mathrm{~kg} \mathrm{P}_{2} \mathrm{O}_{5}\right)$; calculated from data from industry survey in 2004 and the China Statistics Bureau (2004)

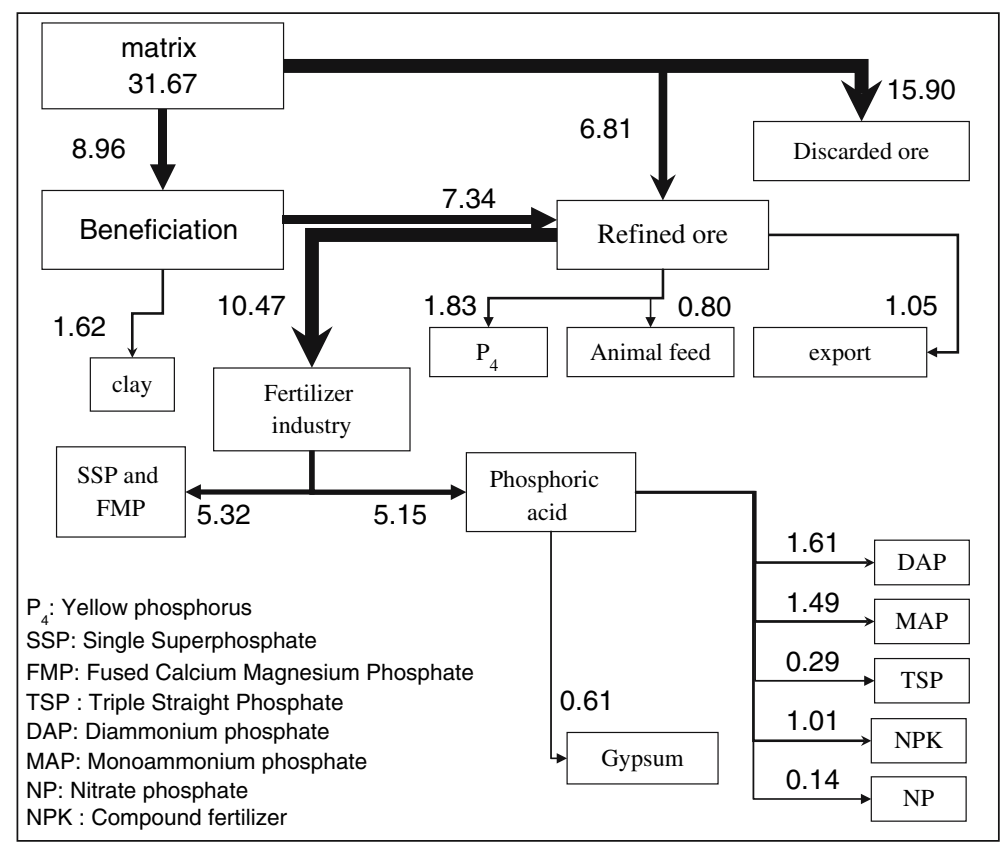


$\mathrm{P}_{2} \mathrm{O}_{5}$ ) and phosphor gypsum, containing $0.61 \mathrm{Tg}$ $\mathrm{P}_{2} \mathrm{O}_{5}$. The phosphoric acid was used to produce highanalysis P fertilizers (DAP, MAP, TSP, NPK, NP), and the phosphor gypsum was discarded with little measures taken to prevent potential pollution. Therefore, the remaining $0.61 \mathrm{Tg} \mathrm{P}_{2} \mathrm{O}_{5}$ in phosphor gypsum was assumed to be the potential pollutant from $\mathrm{P}$ fertilizer plants. Hence, the RUE during $\mathrm{P}$ fertilizer manufacturing $\left(\mathrm{RUE}_{2}\right)$ was $87 \%$. However, the overall RUE in the P fertilizer industry in 2003 was $39 \%$. The low resource use efficiency in the $P$ fertilizer industry is caused mainly by the low recovery rate in the mining of rock phosphate.

Changes in resource use efficiency in the mining of rock phosphate between 1961 and 2003

Mining of phosphate rock was started in China in the 1960s. Until the early 1970s, the mining of rock phosphate remained low and did not match the demand of refined $\mathrm{P}$ rock for the production of $\mathrm{P}$ fertilizer (Table 3). After 1977, with the reform and opening process of China, there was a steady increase in the amount of mined P rock, except for 1985 for the decreased production of $\mathrm{P}$ fertilizer. Since 1995, P rock mining increased steeply, at much faster rate than the production of refined ore and $\mathrm{P}$ fertilizers. From 1995 to 2003, the production of refined rock increased with a growth rate of only $0.5 \mathrm{Tg} /$ per year, but $\mathrm{P}$ rock mining increased with a growth rate of $1.16 \mathrm{Tg} /$ per year and reached $31.7 \mathrm{Tg} \mathrm{P}_{2} \mathrm{O}_{5}$ in 2003, which is equal to nearly $10 \%$ of known deposits of high-grade $\mathrm{P}$ rock.

Before the 1990s, most $\mathrm{P}$ rock mines were operated by 32 large and medium-sized state-owned mining companies with annual production capacities of more than $200 \mathrm{Gg}$. They used modern mining technologies. In the open-pit mines, which accounted for more than $40 \%$ of the total P rock mining, the rate of $\mathrm{P}$ rock recovery was as high as $98 \%$, whereas in the underground mines, accounting for $60 \%$ of the total $\mathrm{P}$ rock mining, $\mathrm{P}$ rock recovery rate was close to $70 \%$. Therefore, the average recovery rate of $\mathrm{P}$ rock mining was near $82 \%$ before 1995 . After 1995, with the increasing demand for high-grade $\mathrm{P}$ rock, a number of small private companies got involved in $\mathrm{P}$ rock mining, often using very simple equipment (pick and shovel), and employing only a few laborers. By
$2003,48 \%$ of the total refined P rock was mined by 424 small enterprises, each with an annual production of less than $20 \mathrm{Gg} \mathrm{P}_{2} \mathrm{O}_{5}$. However, these small enterprises select high-grade $\mathrm{P}$ rock only, and the average recovery rate of $\mathrm{P}$ rock is only $30 \%$ compared with the $98 \%$ rate achieved by those mines using advanced technology. As a consequence, overall $\mathrm{P}$ rock recovery rate $\left(\mathrm{RUE}_{1}\right)$ decreased from about $82 \%$ in the 1980 s to $45 \%$ in 2003 .

The appearance of small, inefficient mines was ascribed to policy support by local governments. Tax rates for big mines (9-10\%) were relatively higher than that for small mines (5-6\%) because the taxes of big mines are usually paid to the central government but the taxes from small mines belong to local government (Pan 2003). Therefore, local governments encouraged the development of small mines in order to get more tax revenue. The small $\mathrm{P}$ rock mining companies use primitive technology and thereby have low costs. These two factors enable small miners to sell products at low price and get high profit in spite of low efficiency. Table 4 describes the situation clearly, that the net sale in yuan per employee and the price of the $\mathrm{P}$ rock sold to the $\mathrm{P}$ fertilizer plant decreased as the size of the mine (in annual production) decreased.

Economics of the phosphorus fertilizer industry

It was estimated from statistical data of the CPFIA that the total revenue of Chinese $P$ fertilizer chain (mine, plant, wholesaler, and retailer) was 74 billion yuan in 2003, which was 47 times higher than in 1994. About $57 \%$ of this revenue was created by the $\mathrm{P}$ rock miners and $\mathrm{P}$ fertilizer manufacturers. The $\mathrm{P}$ fertilizer industry has become an important contributor to the local economy in some regions. For example, the contribution of the $\mathrm{P}$ fertilizer industry to the total economy of Hubei Province was $17 \%$, whereas it was only $1 \%$ for China. The changes in the $\mathrm{P}$ fertilizer industry in China mainly were a consequence of the large differences in gross margins between different products. It was assessed from industry survey data (Table 5) that the total gross profit per unit of product weight was four times higher for the high-analysis P fertilizers (DAP, MAP, TSP, NP, NPK) than for the low-analysis fertilizers (SSP and FMP). The average selling prices of $\mathrm{P}_{2} \mathrm{O}_{5}$ in 
Table 3 Trends in the mining of rock phosphate and in the production of refined ore and phosphate fertilizers ( $\mathrm{Tg}$ ), and the changes of resource use efficiency (RUE), RUE in mining or phosphorus $(\mathrm{P})$ rock recovery rate $\left(\mathrm{RUE}_{1}\right)$ and RUE during fertilizer manufacturing $\left(\mathrm{RUE}_{2}\right)$

\begin{tabular}{|c|c|c|c|c|c|c|c|c|c|}
\hline \multirow[t]{3}{*}{ Year } & \multirow{3}{*}{$\begin{array}{l}\text { Production of } \\
\text { phosphate } \\
\text { fertilizers in } \\
\mathrm{P}_{2} \mathrm{O}_{5}^{\mathrm{a}}\left(P_{\mathrm{pf}}\right)\end{array}$} & \multicolumn{4}{|c|}{ Production of refined $\mathrm{P}$ rock } & \multirow{3}{*}{$\begin{array}{l}\text { Phosphate rock } \\
\text { mining in } \mathrm{P}_{2} \mathrm{O}_{5}^{\mathrm{f}} \\
\left(P_{\mathrm{mr}}\right)\end{array}$} & \multicolumn{3}{|c|}{ P RUE $(\%)^{\mathrm{g}}$} \\
\hline & & \multirow[t]{2}{*}{ Gross weight ${ }^{\mathrm{b}}$} & \multicolumn{3}{|c|}{$\mathrm{P}_{2} \mathrm{O}_{5}$ content } & & & & \\
\hline & & & $\begin{array}{l}\text { Total }^{\mathrm{c}} \\
\left(P_{\mathrm{rr}}\right)\end{array}$ & $\begin{array}{l}\text { Big mine }{ }^{\mathrm{d}} \\
\left(P_{\mathrm{rrb}}\right)\end{array}$ & $\begin{array}{l}\text { Small } \\
\text { mine }^{\mathrm{e}}\left(P_{\mathrm{rrs}}\right)\end{array}$ & & $\mathrm{RUE}_{1}$ & $\mathrm{RUE}_{2}$ & RUE \\
\hline 1961 & 0.15 & 0.00 & 0.00 & 0.00 & & 0.00 & & & \\
\hline 1971 & 1.13 & 2.20 & 0.66 & 0.66 & & 0.81 & 82 & 86 & 71 \\
\hline 1981 & 2.59 & 10.86 & 3.26 & 3.26 & & 3.98 & 82 & 87 & 71 \\
\hline 1991 & 4.64 & 21.00 & 6.30 & 6.30 & & 7.69 & 82 & 88 & 72 \\
\hline 1995 & 6.09 & 26.54 & 7.96 & 7.96 & & 9.72 & 82 & 85 & 70 \\
\hline 1996 & 5.82 & 24.48 & 7.34 & 6.87 & 0.47 & 9.96 & 74 & 86 & 64 \\
\hline 1997 & 6.42 & 27.44 & 8.23 & 7.53 & 0.71 & 11.54 & 71 & 86 & 61 \\
\hline 1998 & 6.71 & 31.77 & 9.53 & 8.13 & 1.40 & 14.60 & 65 & 88 & 58 \\
\hline 1999 & 6.43 & 31.57 & 9.47 & 6.23 & 3.24 & 18.41 & 51 & 89 & 46 \\
\hline 2000 & 6.69 & 34.92 & 10.48 & 5.81 & 4.67 & 22.65 & 46 & 87 & 40 \\
\hline 2001 & 7.45 & 40.50 & 12.15 & 6.30 & 5.85 & 27.19 & 45 & 87 & 39 \\
\hline 2002 & 7.91 & 42.82 & 12.85 & 6.90 & 5.94 & 28.24 & 45 & 87 & 40 \\
\hline 2003 & 9.12 & 47.18 & 14.15 & 7.34 & 6.81 & 31.67 & 45 & 87 & 39 \\
\hline $\operatorname{Sum}^{\mathrm{h}}$ & 133 & 595 & 179 & 150 & 29 & 279 & & & \\
\hline
\end{tabular}

${ }^{a}$ Data from UN-FAO (2004)

b Data from UN-FAO (2004) before 1996, and was calibrated by data from China Statistics Bureau (2004) and Lin (2003) after 1996

c Calculated by the gross weight $\times 30 \%$ (the average $\mathrm{P}_{2} \mathrm{O}_{5}$ content in $\mathrm{P}$ rock is $30 \%$ )

d Data from China Statistics Bureau (2004) before 1996, calibrated by data of Lin (2003) after 1996

e Data from Lin (2003)

f Summed production of big mines/81.9\% + production of small mines/30\% (the recovery rate of big mines and small mines is $81.9 \%$ and $30 \%$, respectively, see text)

g Calculated by the formulas of the substance flow analysis (SFA) model, see text

h All years between 1961 and 2003

Table 4 Size distribution, turnover, and gross profit of phosphorus $(\mathrm{P})$ rock mining in China (after Pan 2003)

\begin{tabular}{lllll}
\hline $\begin{array}{l}\text { Mine size, } \\
\text { (Mg per year) }\end{array}$ & $\begin{array}{l}\text { Share of the } \\
\text { total production } \\
(\%)\end{array}$ & $\begin{array}{l}\text { Net sale (thousand } \\
\text { yuan per employee) }\end{array}$ & $\begin{array}{l}\text { Retail price of } \\
\text { rock product } \\
\text { (yuan per Mg) }\end{array}$ & $\begin{array}{l}\text { Gross margin } \\
\text { (yuan per Mg) }\end{array}$ \\
\hline$>500,000$ & 30 & 578 & 672 & 12 \\
$200,000-500,000$ & 27 & 664 & 528 & 29 \\
$100,000-200,000$ & 14 & 829 & 523 & 7 \\
$50,000-100,000$ & 20 & 188 & 281 & 10 \\
$30,000-50,000$ & 4 & 101 & 326 & 33 \\
$10,000-30,000$ & 4 & 110 & 272 & 26 \\
$<10,000$ & 1 & 63 & 363 & 30 \\
Average & & 410 & 503 & 17 \\
\hline
\end{tabular}

P fertilizers increased from 0.21 yuan per kilogram in 1994 (China Statistics Bureau 2004) to 4 yuan per kilogram $\mathrm{P}_{2} \mathrm{O}_{5}$ in 2003 (Table 5).
The huge profit spurred the local governments to encourage investments in plants producing DAP, MAP, and NPK, which resulted in their booming 
Table 5 The economics of fertilizer products in China in 2003 (yuan/ton)

\begin{tabular}{|c|c|c|c|c|c|c|c|}
\hline \multirow[t]{2}{*}{ Items } & \multicolumn{6}{|c|}{ Cost/price of phosphate fertilizers } & \multirow{2}{*}{$\begin{array}{l}\text { Average cost/price } \\
\text { per ton } \mathrm{P}_{2} \mathrm{O}_{5} \mathrm{a}\end{array}$} \\
\hline & DAP & MAP & NP & TSP & NPK & SSP/FMP & \\
\hline Cost & 1,311 & 1,130 & 717 & 815 & 1217 & 250 & 2,857 \\
\hline Factory price & 1,582 & 1,240 & 1,100 & 1,080 & 1350 & 300 & 3,345 \\
\hline Trade price & 1,680 & 1,330 & 1200 & 1,180 & 1500 & 340 & 3,689 \\
\hline Retail price & 1,750 & 1,410 & 1260 & 1,240 & 1,700 & 380 & 4,047 \\
\hline Gross profit & 439 & 280 & 543 & 425 & 483 & 130 & 1,190 \\
\hline
\end{tabular}

Data of SSP/FMP came from Fan (2001) and the rest came from industry survey (2004). Gross profit = retail price-cost

$D A P$ diammonium phosphate, MAP monoammonium phosphate, NP nitrate phosphate, TSP triple straight super phosphate, NPK compound fertilizer, FMP fused calcium magnesium phosphate, SSP single super phosphate

${ }^{\text {a }}$ Average of all products according to their weight in the total $\mathrm{P}_{2} \mathrm{O}_{5}$ production (see Fig. 1) and the $\mathrm{P}_{2} \mathrm{O}_{5}$ content of each product (see Table 1) in China in 2003

development after the 1990s. Figure 2 presents the trends in production of $\mathrm{P}$ fertilizer in the last decades. The production of $\mathrm{P}$ fertilizer increased by $2.89 \mathrm{Tg}$ from 1995 to 2003, whereas the production of highanalysis P fertilizers (TSP, DAP, MAP, NPK, NP) increased by $3.41 \mathrm{Tg}$. Total production of $\mathrm{P}$ fertilizers reached $9.12 \mathrm{Tg} \mathrm{P}_{2} \mathrm{O}_{5}$ by 2003 , and new production capacities in the last few years were developed almost exclusively to produce high-analysis $\mathrm{P}$ fertilizers. Forecasts based on the industry survey presented that the total $\mathrm{P}$ fertilizer production would be $12.8 \mathrm{Tg} \mathrm{P}_{2} \mathrm{O}_{5}$ in 2010, including capacities to produce $3.9 \mathrm{Tg} \mathrm{P}_{2} \mathrm{O}_{5}$ in SSP, $0.7 \mathrm{Tg} \mathrm{P}_{2} \mathrm{O}_{5}$ in FMP, $3.9 \mathrm{Tg} \mathrm{P}_{2} \mathrm{O}_{5}$ in MAP,

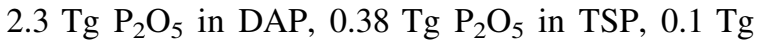
$\mathrm{P}_{2} \mathrm{O}_{5}$ in $\mathrm{NP}$, and $1.5 \mathrm{Tg} \mathrm{P}_{2} \mathrm{O}_{5}$ in NPK.

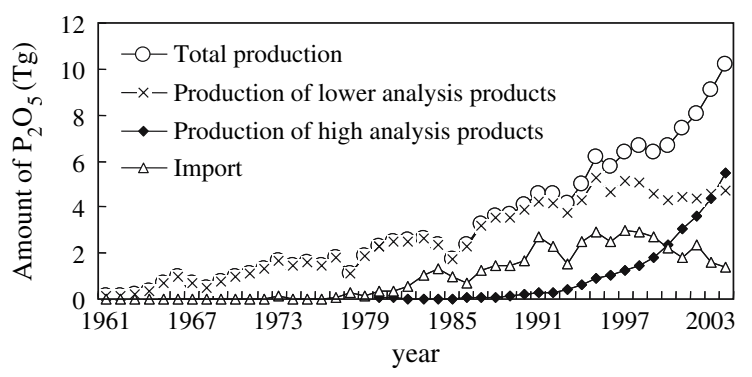

Fig. 2 Trends in production and imports of phosphorus (P) fertilizers in China between 1960 and 2003. High-analysis (high-grade) $\mathrm{P}$ fertilizers include diammonium phosphate $(D A P$ ), monoammonium phosphate $(M A P)$, triple straight super phosphate $(T S P)$, nitrate phosphate $(N P)$, and compound fertilizer $(N P K)$. Low-analysis fertilizers include single super phosphate $(S S P)$ and fused calcium magnesium phosphate $(F M P)$. Import includes all types of $\mathrm{P}$ fertilizers. Data from China Statistics Bureau (2004) and UN-FAO (2004)
The increased revenue does not mean increased efficiency, as China has a huge $\mathrm{P}$ fertilizer industry chain. The CPFIA (2004) reported that the number of $P$ rock mining companies and fertilizer manufacturers was estimated to be 456 and 1,222, respectively, and the number of employees 54,123 and 2,34,354, respectively, in 2003. The large number of producers and employees in the industry resulted in a low economic efficiency. When comparing the economic efficiency in the mines and fertilizer plants in China with that in the USA (Table 6), it was found that Chinese plants (or mines) had relatively low efficiency. The differences in production per employee and net sale per employee for fertilizer manufacturing and in the gross margin per employee in both mining and manufacturing are especially striking.

The booming development in production of highanalysis $\mathrm{P}$ fertilizers was accompanied by a steep increase in $\mathrm{P}$ rock mining from 1995 onward (Table 3). Therefore, the side effect of the booming production of high-analysis fertilizers was a decreasing $\mathrm{RUE}_{1}$ and RUE, but not RUE $\mathrm{R}_{2}$. Technology of fertilizer production is relatively new and advanced, and there is little differences compared with the USA (Table 1). In contrast, $\mathrm{RUE}_{2}$ remained in the narrow range of $86-89 \%$; the small variations reflect variations in product structure. Before 1995, the $\mathrm{P}$ fertilizer industry only comprised big mines producing low-analysis fertilizer products, and the RUE was as high as $71-73 \%$. After 1995 , the growing production of high-analysis fertilizers required high-grade $\mathrm{P}$ rock (the content of $\mathrm{P}_{2} \mathrm{O}_{5}$ more than $30 \%$ after beneficiation), and the central government subsidized 
Table 6 Economic efficiency of the phosphorus (P) industry in China and USA in 2003

\begin{tabular}{|c|c|c|c|c|}
\hline \multirow[t]{2}{*}{ Process of production and marketing } & \multicolumn{2}{|l|}{ Mining } & \multicolumn{2}{|c|}{ Fertilizer manufacturing } \\
\hline & China & USA & China & USA \\
\hline Number of employees per plant (capita) & 119 & 1,818 & 189 & 5,200 \\
\hline Production per employee (ton $\mathrm{P}_{2} \mathrm{O}_{5} /$ capita) & 168 & 537 & 40 & 533 \\
\hline Net sale per employee (US $\$$ a capita) & 10,854 & 47,300 & 25,366 & 421,269 \\
\hline Gross margin per employee (US \$/capita) & 2,927 & 98,516 & 13,659 & 34,846 \\
\hline Data source & Statistical data ${ }^{c}$ & USGS $^{\mathrm{d}}$ & Statistical data & $\mathrm{IMC}^{\mathrm{e}}$ \\
\hline \multicolumn{5}{|c|}{${ }^{a}$ Exchange rate between US $\$$ and yuan was $8.2: 1$} \\
\hline \multicolumn{5}{|l|}{${ }^{\mathrm{b}}$ Gross margin $=$ net sales - cost } \\
\hline \multicolumn{5}{|l|}{ c Data from the statistics of CPFIA (2004) } \\
\hline \multicolumn{5}{|l|}{ d Data from the USGS (2004) } \\
\hline e Data from IMC (2004) & & & & \\
\hline
\end{tabular}

the price of the high-grade $\mathrm{P}$ rock. All $\mathrm{P}$ fertilizers were produced from high-grade $\mathrm{P}$ rock, although lowanalysis fertilizers could be produced from low-grade $\mathrm{P}$ rock with $\mathrm{P}_{2} \mathrm{O}_{5}$ content of $16 \%$. At the same time, all $\mathrm{P}$ fertilizer plants except two were independent from $P$ rock mining according to the industry survey. $\mathrm{P}$ fertilizer plants usually ask for high-grade $\mathrm{P}$ rock only to lower production costs. Moreover, mines and plants are often geographically separated, and the related transportation costs are high. Based on the statistical data of CPFIA, the transportation of $\mathrm{P}$ rock in China was $16 \mathrm{Tg}$ (in gross weight) in 2003, and there was a large incentive to use high-grade $\mathrm{P}$ rock only to reduce costs. Huge demand on the high-grade $\mathrm{P}$ rock and decreased recovery rate in mining and fertilizer manufacturing resulted in a quick decline of RUE (Table 3).

Assessment of the environmental implications of the phosphate fertilizer industry

It was estimated that $140,000-200,000 \mathrm{~km}^{2}$ of land is occupied by mining in China, which took $2 \%$ of the country, and it was growing by $200 \mathrm{~km}^{2}$ per year (Peng et al. 2005). Based on the total amount of refined $\mathrm{P}$ rock mined (179 $\mathrm{Tg}_{2} \mathrm{O}_{5}$, see Table 3) and specific land occupation estimates from the USA, it was calculated that a total of $475 \mathrm{~km}^{2}$ land was occupied by $\mathrm{P}$ rock mines by 2003 , and it has a growth rate of $3.5 \mathrm{~km}^{2}$ per year. But this figure is likely underestimated, because China has large amounts of low-grade $\mathrm{P}$ rock, and mining activities are less well organized compared with those in Florida (Fan 2001; Lv et al. 2002). Although land occupancy by $\mathrm{P}$ rock mining is a minor part of the entire area of mines in China, the effect could be huge, because most of the $\mathrm{P}$ rock mines are located in ecologically fragile regions, such as in Yunnan and Guizhou. The reclamation rate of this land was estimated to be lower than 10\% (Peng et al. 2005), and the accelerated erosion and mud flows in these regions affected more than 2,000 ha per year (Yang 2002). In some mining regions, the average crop land per farmer decreased from 0.06 ha/capita in 1958 to $0.03 \mathrm{ha} /$ capita in 1998 because of erosion and mud flows (Tang 2001).

$P$ rock mines use large amounts of water in the beneficiation step to separate the refined ore from clay. It has been reported for Florida that $37.9 \mathrm{~m}^{3}$ of water was used for the production of $1,000 \mathrm{~kg}$ of refined ore, but $95 \%$ of it was reused (FIPR 2005). Calculated from the production of refined $\mathrm{P}$ rock in China in 2003 (Table 3), the consumption of groundwater was 1.8 billion $\mathrm{m}^{3}$ annually in the $\mathrm{P}$ rock mining process, and the water was contaminated with $\mathrm{P}$, cadmium $(\mathrm{Cd})$, fluoride $(\mathrm{F})$, and other elements from the $\mathrm{P}$ rock. The recycling of water is still in its infancy, so that only $4.23 \%$ of the water can be reused (Peng et al. 2005). Therefore, most of the water is discharged into surface waters and thereby contributes to eutrophication (with $\mathrm{P}$ ) and pollution (with metals and F) of surface water (Lv et al. 2002; Tang 2001; Cheng et al. 1997; Yang 2002).

Phosphor gypsum is a by-product of high-analysis fertilizers and is considered to be the most important 
pollutant of the $\mathrm{P}$ fertilizer industry and is usually stockpiled or dumped. The accumulated total amount of high-analysis fertilizer from 1961 to 2003 was 22.2 $\mathrm{Tg} \mathrm{P}_{2} \mathrm{O}_{5}$ (Fig. 2), and the phosphor gypsum produced with these fertilizers has been estimated to be $110 \mathrm{Tg}$. Phosphor gypsum contains significant quantities of $\mathrm{P}, \mathrm{Cd}, \mathrm{F}$, and radionuclides from the $\mathrm{P}$ rock, and usually has a high acidity. Chinese $\mathrm{P}$ rock has a relatively low content of $\mathrm{Cd}(1-2 \mathrm{mg} / \mathrm{kg}$ matrix) and a relatively high $\mathrm{F}$ content $(10-35 \mathrm{~g} / \mathrm{kg}$ matrix) (Wang 2002; Fan 2001). It was estimated that 0.9-1.9 Gg Cd and 9-33 Tg F have been released into the environment according to the total $931.5 \mathrm{Tg}$ mined matrix (279.45 $\mathrm{Tg}_{2} \mathrm{O}_{5}$, see Table 3). Recent reports indicated that soils around $\mathrm{P}$ fertilizer plants have been enriched with $\mathrm{P}$ (up to $7.5 \mathrm{~g} / \mathrm{kg}$ ), Cd, and F (Lv et al. 2002). Potential risks of the $P$ fertilizer industry have been discussed by Heijde et al. (1990) and Rutherford et al. (1994). The mining and transport of $\mathrm{P}$ rock also leads to formation of dust, which, in the atmosphere, may cause health problems and following its deposition, may contribute to the eutrophication of surface water and the terrestrial ecosystems.

\section{Improving resource use efficiency in China}

The "business as usual" (BAU) scenario has the implication of keeping the RUE at $39 \%$. According to this, $32.8 \mathrm{Tg} \mathrm{P}_{2} \mathrm{O}_{5} \mathrm{P}$ rock will be consumed to produce the projected $12.8 \mathrm{Tg} \mathrm{P}_{2} \mathrm{O}_{5}$ of fertilizer in 2010 (Table 7). About $18.04 \mathrm{Tg} \mathrm{P}_{2} \mathrm{O}_{5}$ would be wasted in mines and $1.96 \mathrm{Tg} \mathrm{P}_{2} \mathrm{O}_{5}$ would be discharged by $\mathrm{P}$ fertilizer plants, which is a potential risk for environmental pollution. The situation seems less sustainable than in 2003. Implementation of scenario 1 involves increase of RUE to $56 \%$ by regulating the use of proper rock phosphate to produce adaptive $\mathrm{P}$ fertilizer products by increasing the price of highgrade $\mathrm{P}$ rock. More than $10 \mathrm{Tg} \mathrm{P}_{2} \mathrm{O}_{5}$ rock phosphates would be saved in this case compared with the BAU scenario. These measures are relatively easy to implement but it would increase the cost of $\mathrm{P}$ fertilizers. Measures included in scenario 2 involve a slight increase in RUE from $39 \%$ to $42 \%$, mainly by improving the fertilizer products' quality to international standards. Thus, $0.95 \mathrm{Tg} \mathrm{P}_{2} \mathrm{O}_{5}$ would be saved in this case in the manufacturing process of $\mathrm{P}$ fertilizers, which would decrease the environmental risk. However, targets are difficult to achieve because Chinese P rock generally comprises higher impurities. Therefore, product quality can rarely match the international level, especially for SSP and FMP, unless improved beneficiation of refined $\mathrm{P}$ rock or updating the technology of $\mathrm{P}$ fertilizer production is achieved.

Implementation of scenario 3 involves increased RUE to $71 \%$ through drastic efficiency improvement of small mines. But this measure would induce decline in $\mathrm{P}$ rock production and thus elevate its price. Therefore, it can be only implemented step by step. Indeed, several local governments promulgated similar regulations to standardize the $\mathrm{P}$ mining and fertilizer industry, in which small mines are allowed to join big ones or are encouraged to improve their technology in 3 or 5 years (PGHB 2004; PGYN 2005). Finally, implementation of scenario 4 yields a significantly higher RUE of $77 \%$ accompanied by low resource depletion and low environmental risk due to drastic efficiency improvement of small mines and better integration between big mines and fertilizer production plants (Table 7).

The room for improving the RUE in the P fertilizer plants is small compared with the measures in P rock mining (increased from $39 \%$ in BAU to $42 \%$ in scenario 2 and to $56 \%$ in scenario 1). However, it must be emphasized that the production of $\mathrm{P}$ fertilizers significantly affects the RUE. The increased $3.86 \mathrm{Tg}_{2} \mathrm{O}_{5}$ (12.8-9.12) in $\mathrm{P}$ fertilizer production in scenarios 1 and 2 resulted in $10-20 \mathrm{Tg} \mathrm{P}_{2} \mathrm{O}_{5}$ more consumption of $\mathrm{P}$ rock compared with that in scenarios 3 and 4. Furthermore, improving the efficiency of fertilizer manufacturing could get a higher RUE of $77 \%$ in scenario 4, which is higher than that before 1995. Therefore, regulating the fertilizer industry is the basic and necessary way to improve RUE in China. Controlling the amount of total fertilizer production or the product structure could change the demand on P rock and, as a result, the RUE. Furthermore, the technologies for mining, beneficiation, ore dressing, and water treatment and recycling are old and inefficient in many $\mathrm{P}$ rock mines, mainly because miners care only about profit and have less incentive to protect resources. But fertilizer plants have more incentives to use resources economically because they must ensure enough materials for long-term development. In our opinion, 
Table 7 Estimates of the 2010 outlook of phosphorus (P) fertilizer production, $\mathrm{P}$ rock use, $\mathrm{P}$ losses, and resource use efficiency for different scenarios (see text)

\begin{tabular}{llllll}
\hline Year/scenario & $\begin{array}{l}\text { Production of } \\
\mathrm{P} \mathrm{fertilizer}_{\left(\mathrm{Tg}_{2} \mathrm{O}_{5}\right)}\end{array}$ & $\begin{array}{l}\text { Use of } \\
\mathrm{P} \text { rock }_{\left(\mathrm{Tg} \mathrm{P}_{5}\right)}\end{array}$ & $\begin{array}{l}\text { Mining loss } \\
\left(\mathrm{Tg}_{2} \mathrm{O}_{5}\right)\end{array}$ & $\begin{array}{l}\text { Manufacturing } \\
\text { loss } \\
\left(\mathrm{Tg}_{2} \mathrm{O}_{5}\right)\end{array}$ & $\begin{array}{l}\text { Resource } \\
\text { use } \\
\text { efficiency (\%) }\end{array}$ \\
\hline Business as usual & 12.80 & 32.80 & 18.04 & 1.96 & 39 \\
Scenario 1 & 12.80 & 22.82 & 8.06 & 1.96 & 56 \\
Scenario 2 & 12.80 & 30.68 & 16.87 & 1.01 & 42 \\
Scenario 3 & 9.12 & 12.79 & 2.31 & 1.35 & 71 \\
Scenario 4 & 9.12 & 11.82 & 2.14 & 0.56 & 77
\end{tabular}

unification of the mines and fertilizer plants could promote implementation of modern advanced technology of the fertilizer industry, and this could increase the $\mathrm{RUE}_{1-2}$ of small mines and then improve RUE greatly (scenario 4).

\section{Discussion}

Recently, Liu et al. (2004) presented a detailed account of the $\mathrm{P}$ flows and budgets for the entire economy and one of the watersheds in China. They concluded that both resource use and RUE had increased in the Chinese economy during the last decades. In their study, P RUE was defined as the total $\mathrm{P}$ flow per unit of gross domestic production (GDP). The data showed that, apart from some annual variations, the GDP increased faster than P fertilizer production, import, and consumption, thus the P RUE increased. Our study shows that the P RUE of the $\mathrm{P}$ fertilizer industry has decreased during the last decades, especially between the 1995 and 2003. In our study, P RUE was defined as the percentage of $\mathrm{P}$ in matrix rock that ends up in $\mathrm{P}$ fertilizer. This consideration has relevance when dealing with scarce and finite resources, such as $\mathrm{P}$ rock.

The fertilizer industry $(3,980 \mathrm{Gg} \mathrm{P}$ in fertilizer in 2003) was clearly the largest external source of $P$ in $P$ flows in China. With respect to eutrophication of surface waters, P pollution by animal wastes $(602 \mathrm{Gg}$ $\mathrm{P})$ is the largest source, whereas runoff from agricultural soils (164 Gg P), detergents in household waste water (105 Gg P) (Liu et al. 2004), and discharge by the $\mathrm{P}$ fertilizer industry $(266 \mathrm{Gg} \mathrm{P})$ are also important sources. Although $\mathrm{P}$ fertilizer production is currently an economically attractive business, it is important to note that the environmental costs of
$\mathrm{P}$ fertilizer production are not accounted for. For instance, miners in Florida spent about US \$1.3 million $/ \mathrm{km}^{2}$ for reclaiming the land following $\mathrm{P}$ rock mining (Brown 2005). Calculating these costs for the Chinese mines would result in annual costs of land reclamation being larger than the GDP of the entire $\mathrm{P}$ fertilizer industry. Also, the costs of treating phosphor gypsum (Schultz 1992) would lower the gross profits of the $\mathrm{P}$ fertilizer industry producing highanalysis P fertilizers by roughly $20 \%$. Decreasing the $\mathrm{Cd}$ content in $\mathrm{P}$ fertilizers would lower the gross profits of the entire $\mathrm{P}$ fertilizer industry by more than 50\% (Lin 2003). Clearly, incorporating the environmental costs in the cost-benefit analyses would change the economics of the $\mathrm{P}$ fertilizer industry greatly.

Both the increased scale and intensity of the environmental problem and the rapid depletion of natural $\mathrm{P}$ resources call for an improved P RUE in the fertilizer industry. The current low RUE in the $\mathrm{P}$ fertilizer industry in China (39\% in 2003) allows huge room for improvement. The scenarios show the RUE could be increased up to $77 \%$ with integrated measures. Increasing RUE could greatly lengthen the duration of the finite $\mathrm{P}$ rock resources in China, and it could also reduce environmental pollution. However, the increase of P RUE requires concerted large efforts from miners, manufacturers, and governments.

Compared with the large opportunity to increase RUE by regulating the fertilizer industry, the possibilities seem smaller in Chinese agriculture. In the last several decades, many agronomists have tried to improve the $\mathrm{P}$ fertilizer recovery rate, but the achievement was inconspicuous. The average application of $\mathrm{P}$ fertilizer on grain crops increased from 22 to $84 \mathrm{~kg} / \mathrm{ha}$ between 1981 and 2003, but the partial factor productivity (PFP) decreased from 130 to 


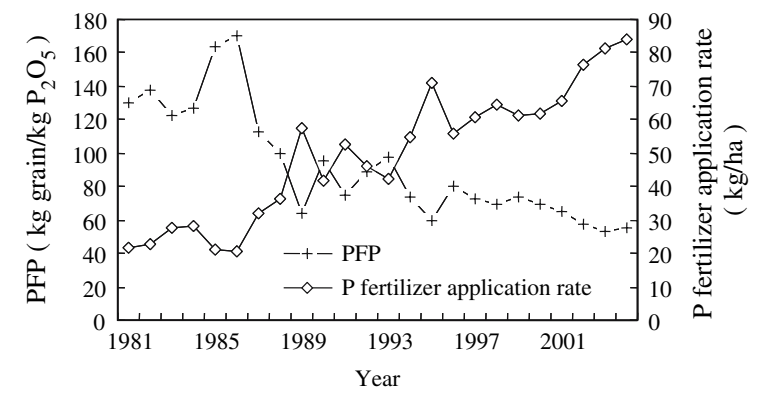

Fig. 3 The tendency of phosphorus (P) fertilizer application and the partial factor productivity (PFP) of $\mathrm{P}$ fertilizer on grain crops in China. PFP is calculated by grain production divided by $\mathrm{P}$ fertilizer used on grain crops, assuming $79 \%$ of total phosphate fertilizer used by grain; $\mathrm{P}$ fertilizer application rate is calculated by $\mathrm{P}$ fertilizer used on grain crops divided by the planting area of grain crops. Data from China Statistics Bureau (2004)

$55 \mathrm{~kg} / \mathrm{kg}$ (Fig. 3). The average recovery rate of $\mathrm{P}$ fertilizer in one season is lower than $20 \%$ in China (Lu and Shi 1980; Lu et al. 1995). In 2010, if the recovery rate of $\mathrm{P}$ fertilizer in agricultural land could be increased by $10 \%$, the demand on $\mathrm{P}$ fertilizer in China would be lower than the level in 2003. That would be helpful in cutting back the production of $\mathrm{P}$ fertilizers and then in improving total $P$ resource use efficiency. Although it seems to be difficult to realize this in the short term, there is space for improving the $P$ RUE by optimizing the entire chain. Efforts to improve agricultural production by advanced technology and to improve manufacturing processes are both important for improving P RUE.

\section{Conclusions}

P RUE in China was proved to decline quickly from $71 \%$ to $39 \%$ between 1995 and 2003. The amount and structure of $\mathrm{P}$ fertilizer use affected RUE significantly because $74 \%$ of $\mathrm{P}$ rock was used to produce fertilizer. After 1995, the P fertilizer industry developed very quickly, with a great increase in the production of highanalysis products such as DAP, MAP, and NPK. The high-analysis products have four times more gross margins than traditional low-analysis fertilizers, and they greatly contributed to the development of some of the regional economies. However, the production of high-analysis fertilizers needs high-grade $\mathrm{P}$ rock, which induced a massive development of $\mathrm{P}$ rock mining. The low efficiency both in mining and in fertilizer production resulted in a great waste of $\mathrm{P}$ resource and produced huge environmental problems. The consumption of high-grade $\mathrm{P}$ resources was $31.67 \mathrm{Tg} \mathrm{P}_{2} \mathrm{O}_{5}$ in 2003 , which was nearly $10 \%$ of the known total deposit. Until 2003, total $179 \mathrm{Tg}_{2} \mathrm{O}_{5}$ was extracted in the refined rock; $475 \mathrm{~km}^{2}$ of land was occupied without reclamation; $110 \mathrm{Tg}$ phosphor gypsum was stockpiled or dumped; and 1.8 billion $\mathrm{m}^{3}$ of groundwater was used annually in the beneficiation of phosphate rock and the wastewater was discharged without treatment. Some of these environmental risks have been reported to produce large effects on the environment. To improve P RUE is very important and urgent for China, and the room to resolve recent problems by modified policies is large, but great concerted efforts are needed in the mining and fertilizer industry and in agriculture.

Acknowledgements This manuscript is based on a number of projects, which were sponsored by the Ministry of Agriculture and Ministry of Commerce of the People's Republic of China, and the Sinochem Company and the Phosphorus Fertilizer Industry Association. Other fertilizer companies also helped a great deal with data acquisition. We appreciate our colleagues L. Ma, L. Wang, L. Cao , and L. Gao for their discussions and help in data analyses. Greatest thanks to Prof. Z.X. Dou, Prof. S.W. Hu, Prof. Y.X. Miao, M. Liu, Prof. S.P. McGrath, and Dr. I. Sisák for their help in revising the paper.

\section{References}

Alexandratos N, de Haen H (1995) World consumption of cereals: will it double by 2025? Food Policy 20(4):359-366

Arrigo KR (2005) Marine microorganisms and global nutrient cycles. Nature 437:349-355

Beman JM, Arrigo KR, Matson PA (2005) Agricultural runoff fuels large phytoplankton blooms in vulnerable areas of the ocean. Nature 434:211-214

Brown MT (2005) Landscape restoration following phosphate mining: 30 years of co-evolution of science, industry and regulation. Ecol Eng 24:309-32

Cai HF (2004) The new problems and counterstrategy for Chinese grain production (in Chinese). Agriculture Product Market Weekly 10-12

Cheng SG, He Y, Wang YL (1997) Effects of phosphorus resource mining project on ecology (in Chinese). Environ Countermeas 16(2):4-6

China Statistics Bureau (2004) China statistic yearbook (in Chinese). China Statistics Press, Beijing

China Phosphate Fertilizer Industry Association (CPFIA) (2004) The technique and economic yearbook of sulfuric and phosphorus industry in China. http://www.Chinanpk.com 
Decyfer Ltd (2005) Raw material consumption. http://www. decyfer.com/ccf.htm

Fan KZ (2001) China fertilizer manual (in Chinese). China National Chemistry Information Center, Beijing

Florida Institute of Phosphate Research (FIPR) (2005) Overview of mining and mineral processing in Florida. http://www.fipr.state.fl.us/research-area-mining.htm

Heijde HB Van Der, Klijn PJ, Duursma K, Eisma D, De Groot AJ, Hagel P, Koster HW, Nooyen JL (1990) Environmental aspects of phosphate fertilizer production in the Netherlands with particular reference to the disposal of phosphor gypsum. Sci Total Environ 90:203-225

IFA (2004) World agricultural situation and fertilizer demand, global fertilizer supply and trade 2003/04-2008/09. IFA Annual Conference. http://www.fertilizer.otg

IMC (2004) IMC global overview in 2003. http://www. imcglobal.com

Lin L (2003) The situation and prospect of China phosphorus fertilizer industry (in Chinese). China Pet Chem Ind (Z1):38-39

Liu JG, Diamond J (2005) China's environment in a globalizing world-How China and the rest of the world affect each other. Nature 435(30):1179-1186

Liu Y, Mol APJ, Chen J (2004) Material flow and ecological restructuring in China: the case of phosphorus. J Ind Ecol 8(3):103-120

Lu RK, Shi TJ (1980) Consumption and accumulation of soil phosphorus in utilizing (in Chinese). Chin J Soil Sci 11(5):6-8

Lu RK, Shi ZY, Gu YC (1995) Research on the accumulated phosphorus of soil II-The apparent use efficiency of phosphorus fertilizer (in Chinese). Soil 27(6):286-289

Lv YF, Cao JX, Wang ZQ (2002) The formation of environmental pollution in phosphate mine and its prevention (in Chinese). Conserv Util Miner Resour (6):10-15

Murray P (2003) The fertilizer industry (in Chinese). Publishing House of the Chinese Customs, Beijing, pp 70-77

Pan CY (2003) A study on the phosphorus mineral resources in Yunnan and the policy of its sustainable utilization (in Chinese). Yunnan Ecol 22(3):336-341

Peng J, Jiang YJ, Wu JS, Liu S (2005) Eco-environmental effects of mining and related land reclamation technologies in China (in Chinese). Progr Geogr 24(2):38-48

Rutherford PM, Dudas MJ, Samek RA (1994) Review articleEnvironmental impacts of phosphor gypsum. Sci Total Environ 149:1-38
Schultz JJ (1992) An examination of the environmental issues facing the phosphate fertilizer production sector-indicated cost of environmental Compliance. In: Schultz JJ (ed) Phosphate fertilizers and the environment, Proceedings of an international workshop, IFDC paper series IFDC-SP18, Muscle Shoals, AL, pp 283-310

Smil V (2000) Phosphorus in the environment: natural flows and human interferences. Annu Rev Energy Environ 25:53-88

Tang XY (2001) Mine exploitation and environmental synthetic treatment at Yangshui field in Kaiyang phosphorite of Guizhou (in Chinese). Guizhou Geol 18(1):64-67

The People's Government of Hubei Province (PGHB) (2004) Temporary approaches for managing phosphate mine (in Chinese). http://www2.cnhubei.gov.cn

The People's Government of Yunnan Province (PGYN) (2005) Criterion for entry into phosphate rock mining (in Chinese). http://www.yn.gov.cn

Tinker PB (1977) Economy and chemistry of phosphorus. Nature 270:103-104

U.S. Geological Survey (USGS) (2004) Mineral commodity summaries. http://www.minerals.usgs.gov/minerals/pubs/ commodity/phosphate_rock

UN-FAO (2004) FAO statistical databases. http://www. faostat.fao.org/

Wang JP (2002) Cd level in high analysis phosphate fertilizer after WTO accession (in Chinese). Phosphate Compd Fertilizer 17(5):11-15

Yang XC (2002) Mass extraction induced ecological tragedy: what happened in Guizhou Kaiyang phosphate field (in Chinese). People's Daily. http://www.china.org.cn/ chinese/huanjing/190867.htm

Zhang FS, Ma WQ, Zhang WF, Fan MS (2005a) Nutrient management in China: from production systems to food chain. In: Li CJ et al (eds) Plant nutrition for food security, human health and environmental protection. Tsinghua University Press, Beijing, pp 13-15

Zhang WF, Gao L, Ma J, Ma WQ, Xu XC, Zhang FS (2007) Evaluation on the reform effectiveness of fertilizer industry policy in China (in Chinese). Phosphate Compd Fertilizer 22(1):5-9

Zhang WF, Ma WQ, Zhang FS, Ma J (2005b) Comparing the superiority of Chinese phosphate rock and the using strategy with that of United States and Morocco (in Chinese). J Nat Resour 20(3):378-386 